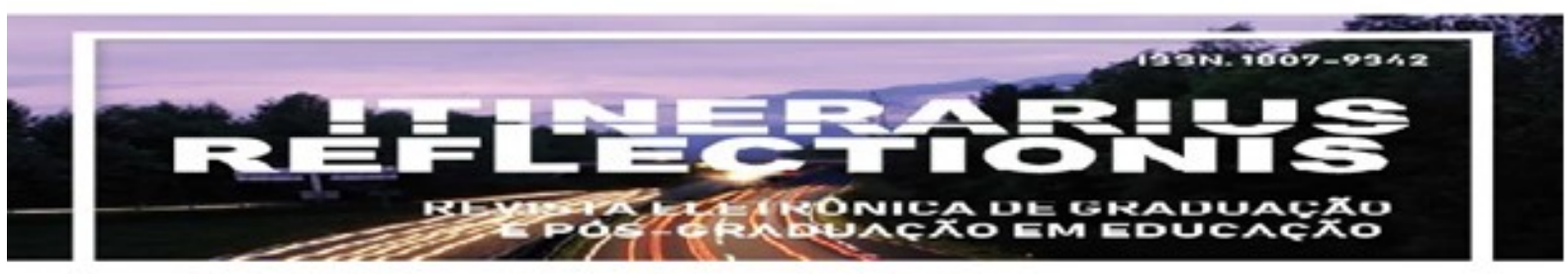

Volume 15, número 1, ano, 2019

\title{
IDENTIDADE E PERFIL DOS PROFESSORES UNIVERSITÁRIOS: REFLEXOS E INFLUÊNCIAS NA DOCÊNCIA E NA FORMAÇÃO ACADÊMICA
}

\section{IDENTITY AND PROFILE OF PROFESSORS: REFLECTIONS AND INFLUENCES IN TEACHING AND ACADEMIC TRAINING}

\author{
Joice Silva Marques Mundim ${ }^{1}$ \\ Giselle Moraes Resende Pereira ${ }^{2}$ \\ Guilherme Saramago de Oliveira ${ }^{3}$
}

Resumo. Esta pesquisa tem como foco principal a docência universitária, com ênfase na identidade e perfil dos professores e, também, a formação acadêmica destinada aos estudantes universitários. O objetivo deste artigo é investigar, analisar e discutir sobre a identidade e perfil dos professores do Ensino Superior, abordando o significado e a finalidade da docência para a formação acadêmica dos alunos. Visto que a identidade e o perfil dos professores universitários influenciam no processo de ensino-aprendizagem, na construção de conhecimentos e na formação dos sujeitos, foi aplicado um questionário para 18 professores que ministram aulas no curso de Agronomia da Universidade Federal de Uberlândia, Campus Monte Carmelo, em que permitiu delinear uma discussão acerca da docência

\footnotetext{
${ }^{1}$ Graduação em Pedagogia pela Universidade Federal de Uberlândia (2011). Especialização em Docência na Educação Infantil e Séries Iniciais pela Universidade Cândido Mendes (2012). Especialização em Psicopedagogia e Educação Especial pela Universidade Cândido Mendes (2013). Mestrado em Educação pela Universidade Federal de Uberlândia (2015). Doutoranda em Educação pela Universidade Federal de Uberlândia. joicemmundim@hotmail.com

${ }^{2}$ Professora da Faculdade de Matemática da Universidade Federal de Uberlândia (UFU), campus Monte Carmelo/MG, e doutoranda do Programa de Pós-graduação em Educação da UFU, linha de pesquisa Educação em Ciências e Matemática. Possui graduação em Matemática (Bacharelado) pela Universidade Federal de Uberlândia (2009), graduação em Matemática (Licenciatura) pela Universidade de Franca (2011), mestrado em Matemática pela Universidade Federal de Uberlândia (2012) e curso de extensão universitária em Educação a Distância pelo Centro Educacional Sul Mineiro LTDA-ME, CESM (2016). gisellemr@gmail.com

${ }^{3}$ Graduado em Pedagogia pela Universidade Federal de Uberlândia (1986). Graduado em Direito pela Universidade Federal de Uberlândia (1991). Graduado em Matemática pela Universidade de Uberaba (2009). Mestre em Ensino Superior pela Pontifícia Universidade Católica de Campinas (1997). Mestre em Inovação e Sistemas Educativos pela Universidade Autônoma de Barcelona (1999). Doutor em Educação pela Universidade Federal de Uberlândia (2009). Atuou como Professor da Educação Infantil, Ensino Fundamental e Médio. Exerceu as funções de Supervisão Escolar e Direção de Escola de Educação Básica. Foi Assessor Técnico Pedagógico da Secretaria Municipal de Educação e Secretário Municipal de Educação Interino - Uberlândia MG. Atualmente é Professor Associado da Universidade Federal de Uberlândia, lotado na Faculdade de Educação FACED/UFU - onde desenvolve ações de Ensino, Pesquisa, Extensão e Administração, na Graduação e nos Programas de Pós-Graduação acadêmico e profissional. É Diretor de Ensino da Pró-Reitoria de Graduação da Universidade Federal de Uberlândia. Compõe o corpo de avaliadores de cursos superiores presenciais e a distância do INEP/MEC.gs.oliveira@ufu.br
} 


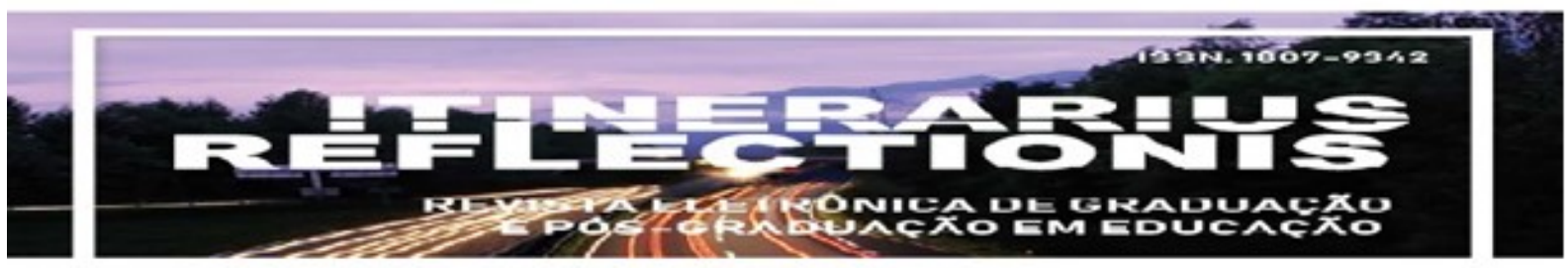

Volume, 15, número 1, ano 2019

universitária, a partir de diversos aspectos relacionados com o ensino e a formação dos discentes. Nesse sentido, foi possível destacar pontos pertinentes desta temática, a partir das falas dos professores colaboradores da pesquisa. Este trabalho é fruto da disciplina Seminários de Pesquisa em Educação de Ciências e Matemática III: Educação Superior (PGED076) ofertada pela Linha de Pesquisa Educação de Ciências e Matemática, no curso de Doutorado em Educação, fundamentando nossas reflexões sobre os professores universitários e sua contribuição para a formação dos alunos.

Palavras-chave: Docência Universitária. Identidade. Perfil. Formação Acadêmica.

\begin{abstract}
This research has mainly focused on university teaching, with an emphasis on identity and profile of professors, and also academic training for university students. The purpose of this article is to investigate, analyze and discuss the identity and profile of professors, addressing the meaning and purpose of teaching for the academic training of the students. Since the identity and profile of professors influence the teaching-learning process in the construction of knowledge and training of the subjects, a questionnaire was applied to eighteen professors, who teach classes in the course of Agronomy of the Federal University of Uberlândia, Campus Monte Carmelo, where allowed to construct a discussion about the university teaching, from various aspects related to education and training. In this sense, it was possible to highlight relevant points of this subject, from the speeches of collaborating professors research. This work is the result of the Seminar of Research in Science and Mathematics Education III: Higher Education (PGED076) offered by the Research Line of Science and Mathematics Education, in the Doctoral Degree in Education, grounding our reflections on university professors and their contribution for the training of students.
\end{abstract}

Keywords: University Teaching. Identity. Profile. Academic training

\title{
1 INTRODUÇÃO
}

A docência envolve diversos papéis que influenciam na atuação do professor universitário, dentre eles estão, as responsabilidades no processo de ensino-aprendizagem, a formação de um indivíduo crítico, as construções didático-pedagógicas, sendo estes aspectos essenciais para contribuir na formação dos discentes e para o aprimoramento da carreira do docente. O professor, enquanto um dos elementos mediadores, possui atribuições de intervir no desenvolvimento educacional dos discentes, viabilizando situações que propiciem a construção de conhecimentos.

O objetivo geral deste trabalho é despertar reflexões sobre a docência universitária, visto que, se trata de uma profissão com identidade nem sempre bem estabelecida e esclarecida que carrega muitos questionamentos, preocupações e 


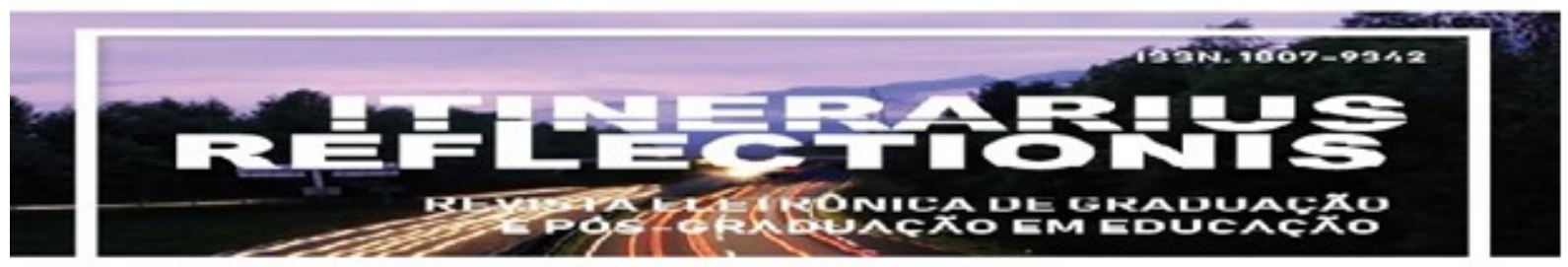

Volume, 15, número 1, ano 2019

reponsabilidades. Nesse sentido, buscamos especificamente investigar, analisar e discutir sobre a identidade e perfil dos professores do Ensino Superior, abordando o significado e finalidade da docência para a formação acadêmica.

Diante da temática, busca-se esclarecer quais os reflexos e influências da identidade e perfil dos professores do Ensino Superior, do curso de Agronomia da Universidade Federal de Uberlândia, Campus Monte Carmelo, sob uma perspectiva didática e pedagógica, na docência e na formação acadêmica?

Para alcançar os objetivos e responder o problema em questão, utilizou-se a pesquisa qualitativa, realizada a partir de um questionário, como instrumento de coleta de dados. O questionário foi disponibilizado online, por um período determinado, contando com a colaboração de 18 professores, que ministram aulas no curso de Agronomia da Universidade Federal de Uberlândia (UFU), Campus Monte Carmelo, sendo: 14 professores lotados no Instituto de Ciências Agrárias (ICIAG), 1 na Faculdade de Gestão e Negócios (FAGEN), 1 no Instituto de Geografia (IG) e 2 na Faculdade de Matemática (FAMAT).

O público-alvo da pesquisa, professores no curso de Agronomia da UFU/Campus Monte Carmelo, foi selecionado por ser o ambiente de trabalho, de vivências práticas e de estudos dos autores desta pesquisa. Os colaboradores foram escolhidos mediante disponibilidade e interesse de participação na temática proposta.

O questionário foi composto por questões fechadas e abertas, sendo analisadas a partir da análise de conteúdo, seguindo as categorias: gênero, local de trabalho, formação, profissão, tempo de atuação no Ensino Superior, conhecimento dos professores sobre o projeto pedagógico do curso de Agronomia, incentivo para ser professor, significado de ser professor, qualidade de uma boa aula, características de um bom aluno, avaliação do professor em relação a aprendizagem do aluno, reprovação nas disciplinas, formação docente, participação em grupo de pesquisa e orientação de alunos de graduação em projetos de iniciação científica. 


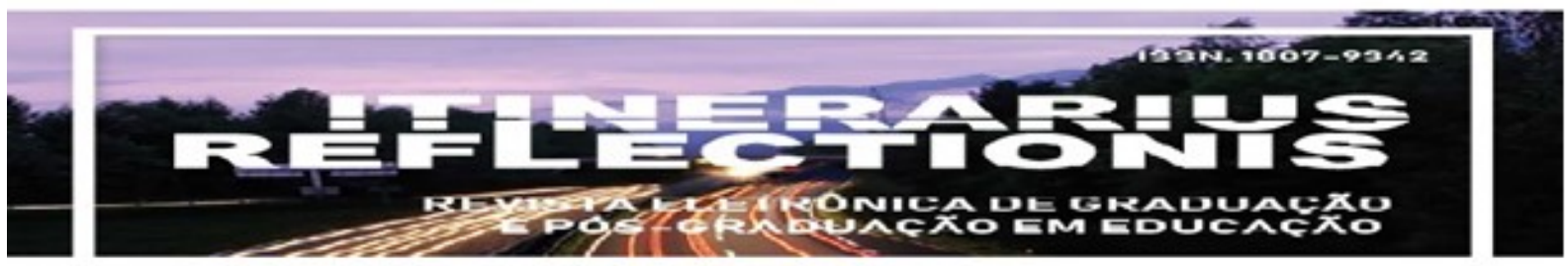

Volume, 15, número 1, ano 2019

Segundo Minayo (1997), a pesquisa qualitativa se organiza em agrupar o significado e a intencionalidade como essenciais às atuações, às relações sociais e às estruturas seguidas, adotadas como construções humanas significativas. E ainda, de acordo com a autora, na pesquisa qualitativa, a metodologia de pesquisa "[...] é o caminho do pensamento a ser seguido, ocupa um lugar central na teoria e trata-se basicamente do conjunto de técnicas a ser adotada para construir uma realidade" (MINAYO, 2003, p. 16-17).

Para Rossman e Ralis (1998), as características da pesquisa qualitativa abordam um cenário natural; métodos múltiplos que são interativos e humanísticos; discussões flexíveis; interpretações e reflexões sobre fenômenos sociais que se procura pesquisar.

O questionário, segundo Gil (1999, p. 128), pode ser definido "como a técnica de investigação composta por um número mais ou menos elevado de questões apresentadas por escrito às pessoas, tendo por objetivo o conhecimento de opiniões, crenças, sentimentos, interesses, expectativas, situações vivenciadas, etc."

Para analisar a coleta de dados recorremos a análise de conteúdo, que segundo Franco (2007, p. 12), “O ponto de partida da Análise de Conteúdo é a mensagem, seja ela verbal (oral ou escrita), gestual, silenciosa, figurativa, documental ou diretamente provocada". E ainda, "a análise de conteúdo é um procedimento de pesquisa que se situa em um delineamento mais amplo da teoria da comunicação e tem como ponto de partida a mensagem”. (FRANCO, 2007, p. 23).

A partir dessas considerações será delineada uma discussão fundamentada nas reflexões e nas análises da pesquisa realizada com os professores do Ensino Superior, apoiando em referenciais bibliográficos sobre a identidade e o perfil da docência universitária, abordados na disciplina em curso do Doutorado.

Este trabalho é fruto da disciplina Seminários de Pesquisa em Educação de Ciências e Matemática III: Educação Superior (PGED076) ofertada pela Linha de Pesquisa Educação de Ciências e Matemática, no curso de Doutorado em Educação, com a proposta de 


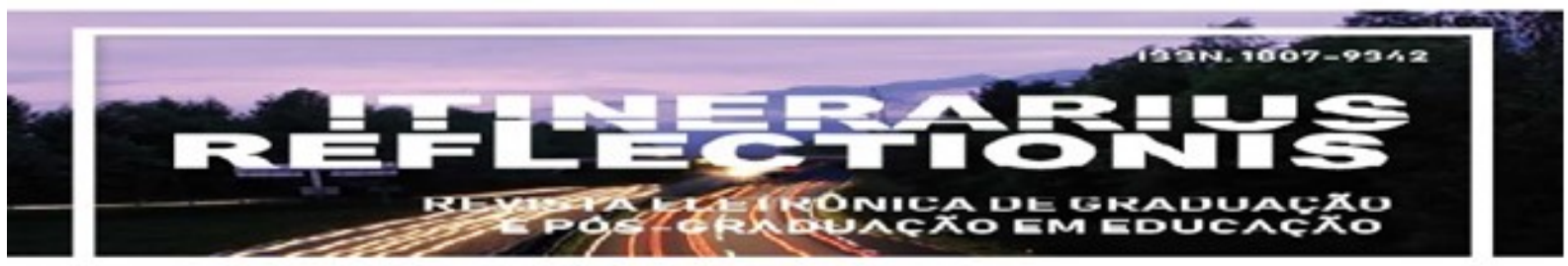

Volume, 15, número 1, ano 2019

trabalhar as temáticas relacionadas ao Ensino Superior, em ênfase a relevância do papel do professor na formação acadêmica dos estudantes universitários. As vivências práticas e as leituras acompanhadas de discussões nessa disciplina, nos impulsionaram e se fez necessário abordar esta temática, para refletirmos sobre a identidade e perfil dos docentes universitários e qual o impacto dessas construções no processo de ensino-aprendizagem dos discentes.

\section{DOCÊNCIA UNIVERSITÁRIA: IDENTIDADE E PERFIL DOS PROFESSORES}

Sem pretensão de caracterizar e definir um perfil para os participantes da pesquisa iremos expor algumas ideias e reflexões que permearão este artigo, a partir do levantamento de dados e das discussões de autores da área.

O professor universitário, ao longo de sua atuação profissional, define suas práticas pedagógicas, adota e/ou constrói concepções ${ }^{4}$ e, consequentemente, define sua identidade e perfil à medida que desenvolve as funções de ensino, pesquisa, extensão e gestão. Zabalza (2004), atribui três funções aos professores universitários: o ensino (docência), a pesquisa e a administração nos setores da instituição. E ainda, Zabalza (2002), considera que a docência universitária está ligada a três ideais: profissionalismo, por envolver características complexas que demanda de formação específica, à aprendizagem ao longa da vida, que exige uma formação continuada e, a influência da qualidade docente na melhoria da aprendizagem.

A atuação docente é marcada pela necessidade de aprimoramentos e qualificação didático-pedagógica para corresponder às expectativas e exigências do processo de ensinoaprendizagem e da formação do sujeito. Como afirma Gil (2009, p. 16) "A preparação pedagógica do professor universitário, não constitui tarefa fácil", pois envolve uma série de

${ }^{4}$ A palavra concepções está apoiada na abordagem proposta por Malusá, Ferreira e Pedrini (2016) como conceitos valorativos atribuídos pelos docentes, ou seja, as atitudes adotadas pelos professores em consonância com suas convicções. 


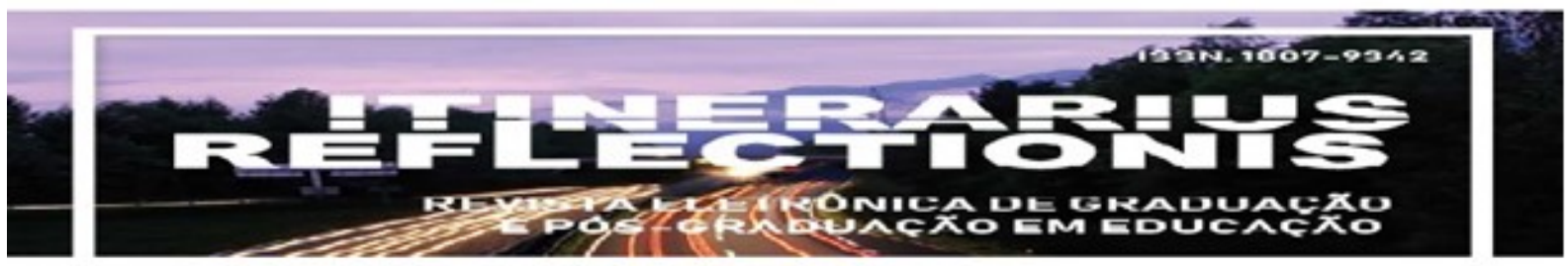

Volume, 15, número 1, ano 2019

fatores que se ligam à tradição dos cursos, às visões pré-estabelecidas sobre docência, à necessidade de especializações mais precisas, entre outros.

Nesse sentido, o contexto de docência tem tomado outros rumos com as novas reformas e atualizações no contexto educacional, em que:

O conceito de docência passa a não se constituir apenas de um ato restrito de ministrar aulas, nesse novo contexto, passa a ser entendido na amplitude do trabalho pedagógico, ou seja, toda atividade educativa desenvolvida em espaços escolares e não-escolares pode-se ter o entendimento da docência. (LIBÂNIO, 2007, p. 23).

Todas as atividades educativas, a partir do entendimento da docência, levam em consideração a identidade, o perfil, as práticas pedagógicas e as concepções dos professores, justificando a relevância de cada um desses aspectos e a influência dessas construções para a formação.

Baseado em Guimarães (2011), a docência é formadora da identidade profissional do professor. Os professores devem considerar as singularidades e os conhecimentos que são próprios da profissão.

Embora a identidade profissional se vincule ao conhecimento (e também atuação profissional) em determinada área de estudos, o que determina o professor não é o fato de ser expert em uma determinada área, mas o fato de lidar com o ensino. $\mathrm{O}$ fato de ensinar. (GUIMARÃES, 2011, p. 20).

O processo de ensino-aprendizagem permeia toda a trajetória do professor, sendo considerado um dos aspectos de maior influência da prática pedagógica e dos planejamentos, em que a identidade e o perfil dos profissionais fazem a diferença nessas construções.

A partir do destaque da identidade e do perfil do professor universitário, para aprofundar nesse estudo, apresenta-se a seguir os participantes desta pesquisa, bem como os dados coletados referente às ações da docência. Ao todo foram 14 professores lotados no Instituto de Ciências Agrárias (ICIAG), 1 (um) na Faculdade de Gestão e Negócios (FAGEN), 1 (um) no Instituto de Geografia (IG) e 2 (dois) na Faculdade de Matemática (FAMAT), atuantes no Campus Monte Carmelo, da Universidade Federal de Uberlândia (UFU). 


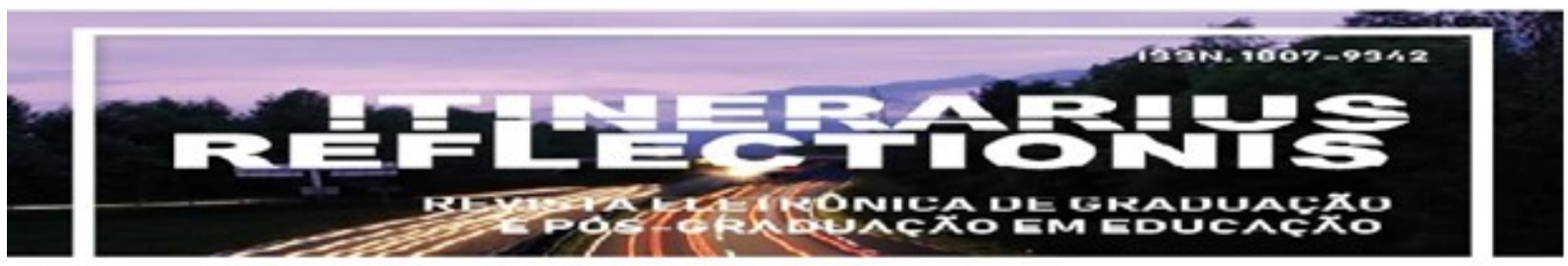

Volume, 15, número 1, ano 2019

Sobre o gênero dos participantes, 8 são do sexo feminino (correspondendo a $44,4 \%$ dos participantes) e 10 do sexo masculino (correspondendo a 55,6\% dos participantes), todos de nacionalidade brasileira.

O tempo de ingresso na carreira docente dos colaboradores desta pesquisa varia entre 2 a 13 anos, sendo a maioria iniciantes na carreira universitária. Mediante esse dado, reflete-se que, segundo Grillo (2006, p. 69), "As razões que levam o professor a encaminharse à docência estão bastante associadas ao conhecimento científico e à experiência profissional", em que algumas atuações e situações de ensino em outros ambientes de trabalho, semelhantes às salas de aula, influenciam visões para seguir a carreira do magistério. Além disso, a autora também destaca que "A opção pela docência traz também marcas de exprofessores que influenciaram os novos, o que pode explicar certas representações sobre professor" (GRILLO, 2006, p. 69).

Diante disso, as responsabilidades docentes crescem, no que diz respeito à formação, pois esses profissionais têm a capacidade de influenciar em diversos sentidos, na construção de concepções, na escolha de atuações e no processo de ensino-aprendizagem. Todas essas influências também refletem nas características da identidade e do perfil dos professores universitários, em que alguns aspectos marcam e espelham como exemplos nos momentos de planejamento, atuação em sala de aula e na construção de concepções sobre a área de trabalho.

A questão da identidade e do perfil dos professores universitários, além de representar um aspecto pertinente na carreira docente, revela que a partir dessas construções há o desenvolvimento e o desempenho das funções pedagógicas, administrativas e pessoais, como define Zabalza (2004).

Para tratar sobre identidade e perfil de professores é essencial identificar sua formação, assim os participantes desta pesquisa, a definiram: Zootecnista (2 professores); Doutorado (2 professores); Agronomia (2 professores); Engenheiro Agrônomo (2 


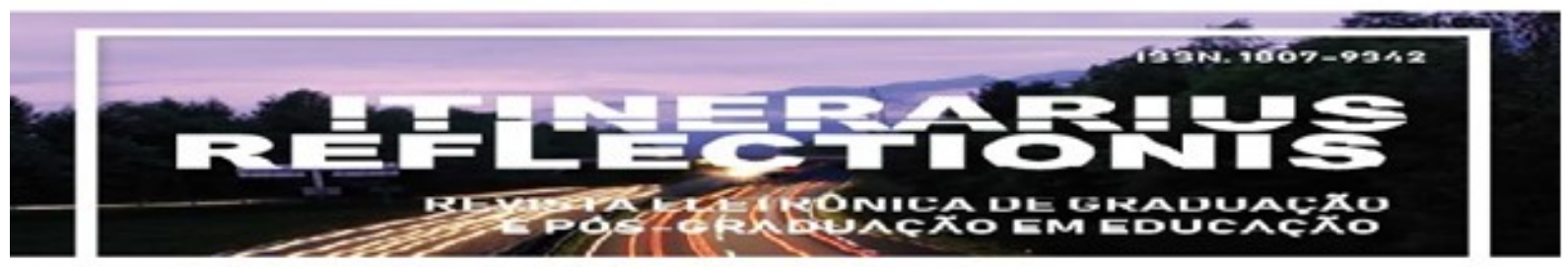

Volume, 15, número 1, ano 2019

professores); Administração (1 professor); Matemática e Pós Doutorado em Física Matemática (1 professor); Engenharia Cartográfica (1 professor); Doutor em Fitopatologia (1 professor); Engenheiro Agrônomo e Doutor em Ciência do Solo (1 professor); Doutor em Microbiologia Agrícola (1 professor); Biólogo (1 professor); Engenharia Agrícola Pósdoutorado (1 professor); Doutorado e Mestrado em Agronomia/Fitotecnia (1 professor) e Mestrado (1 professor).

A formação é a base da atuação do professor, considerando ser a precursora para a definição de concepções, práticas pedagógicas e estratégias didáticas na atuação profissional. Os professores, colaboradores da pesquisa, possuem formações específicas nas áreas de atuação, para o curso de bacharelado em Agronomia da Universidade Federal de Uberlândia (UFU), Campus Monte Carmelo, sendo um aspecto positivo para a formação dos discentes, considerando o domínio especifico dos conteúdos da área.

Entre os 18 participantes, 16, que correspondem a 88,9\%, participam de algum grupo de pesquisa na universidade e 13 já participaram de algum curso de formação docente, o que equivale a $72,2 \%$ dos colaboradores. A respeito dos cursos de formação, alguns participantes mencionaram o Curso de Docência Universitária, oferecido pela Pró-Reitoria de Graduação - PROGRAD e Diretoria de Ensino - DIREN da UFU; o Curso de Uso da voz pelo docente na Universidade Estadual de Maringá - UEM; o Curso didático-pedagógico; o Curso Docência Universitária; Docência no Ensino Superior DIFDO, no Campus Monte Carmelo UFU e o Curso de Docência Universitária, promovido pela Divisão de Formação Docente DIFDO da UFU.

A maioria dos professores já participou de algum curso especializado para docência universitária. Diante desses dados, considera-se que estes possuem conhecimentos para a atuação, a partir de uma perspectiva didático-pedagógica, incluindo todos os conteúdos, inclusive os que se concentram nas disciplinas exatas. 


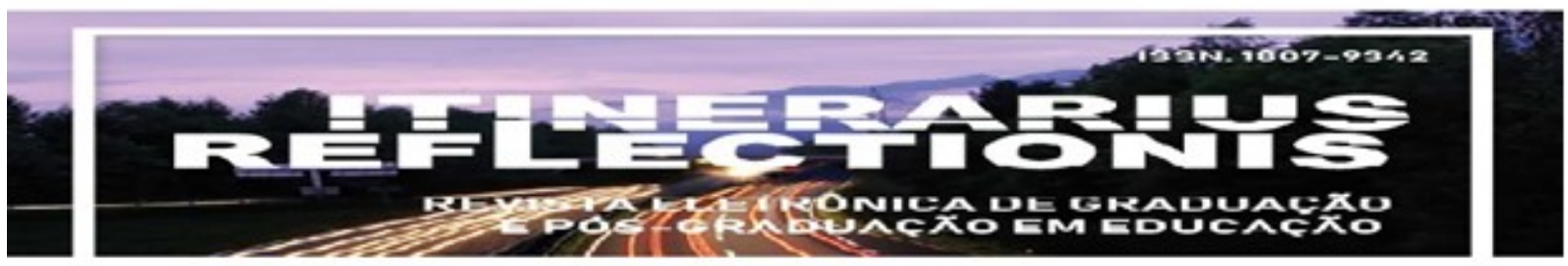

Volume, 15, número 1, ano 2019

Baseados em Zabalza (2004), é possível que, durante a atuação docente, alguns professores universitários acabem focando apenas no ensino, não assumindo seu compromisso profissional de propiciar que os alunos aprendam. $\mathrm{O}$ ensino não é apenas explicar, argumentar e apresentar, ele abarca também o processo de aprendizagem, a construção de conhecimentos. O exercício da docência, em qualquer nível, requer uma sólida formação em conteúdos científicos, e também, uma consistente e ampla formação pedagógica, assim, percebe-se a relevância dos cursos voltados para a docência universitária.

A identidade do professor está alicerçada no que ele sente sobre o que é, sobre o que sabe, sobre os interesses e afinidades profissionais, sobre os eventos científicos que participa, sobre as conversas com colegas etc. De acordo com Zabalza (2004), a docência universitária é muito contraditória no sentido de que muitos professores universitários se auto definem, valorizando mais o âmbito científico do que suas atividades docentes, ou seja, a identidade do professor se deposita no conhecimento sobre a especialidade e não sobre a docência.

Durante a pesquisa realizada com os 18 professores, destacam-se dois pontos chaves, sendo: "Qual a sua profissão?" e o "O que é ser professor para você?" que nos remetem a reflexão sobre a docência, as características da formação, da identidade e do perfil dos professores.

Em relação ao questionamento sobre a identidade profissional, 8 responderam que são professores, 3 que são docentes, 1 que é professor universitário, 1 que é professor do ensino superior, 1 que é docente servidor público, 3 que são engenheiros agrônomos e 1 que é agrônomo. Percebe-se que a maioria repousa sua atuação na docência, oferecendo pistas sobre a dimensão profissional do docente universitário, e que poucos centraram suas atividades profissionais em suas especialidades científicas.

Diante dessa questão, Zabalza (2004) nos faz refletir sobre alguns questionamentos relacionados com esse ponto da identidade profissional: 


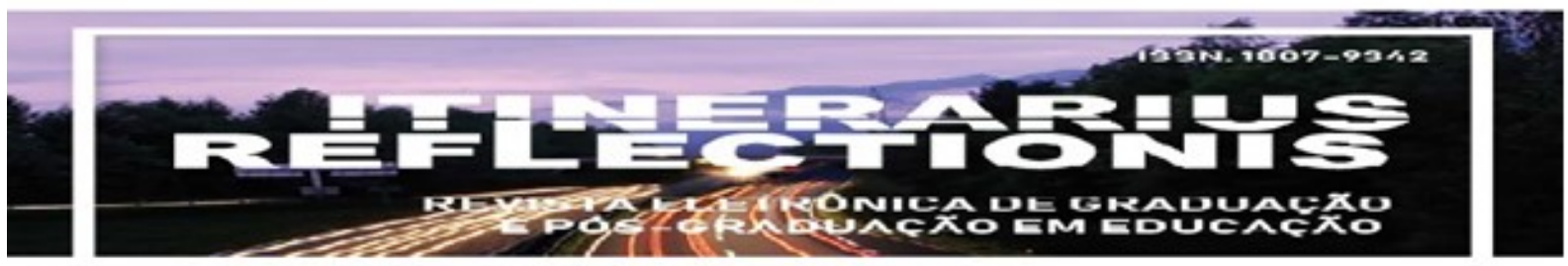

Volume, 15, número 1, ano 2019

A docência universitária é uma profissão ou é o trabalho que exercemos? Qual é o eixo em torno do qual é construída a identidade profissional? Quando cabe a nós dizer o que somos, como nos auto definimos: como sociólogos, economistas, advogados, engenheiros, médicos ou como professores da universidade? (ZABALZA, 2004, p. 107).

Nesse sentido, as considerações dos professores, no que se refere à sua atividade profissional e à carreira docente, variam entre o reconhecimento de ser professor, o status de identificar-se como professor universitário e o de valorizar mais o âmbito científico, sendo professores e definindo-se como engenheiros.

Outro ponto de reflexão sobre a identidade profissional é a preparação para a prática docente que de acordo com Zabalza (2004, p. 107), no que diz respeito à preparação, esta "esteve sempre orientada para o domínio científico e/ou para o exercício das atividades profissionais vinculadas a ele". Entretanto, esse conhecimento não pode ser o único a compor à docência universitária, visto que a atuação do professor abrange conhecimentos práticos, domínio de conteúdos, formação didático-pedagógica, entre outros.

E ainda, de acordo com Zabalza (2004):

A recuperação, ainda incerta, da natureza profissional da atividade docente exigiu, como condição prévia, separá-la das outras dimensões que caracterizam e completam a identidade da ocupação de professor universitário; isto é, separar a atividade docente da atividade de pesquisa e de administração que também caminham juntas ao papel de professores. (ZABALZA, 2004, p. 108).

A valorização em ser professor, as diversas atuações e atividades educacionais escolares e não-escolares presentes na carreira docente, destacam a pertinência desse trabalho no processo de ensino-aprendizagem, na construção de conhecimentos, na formação e na edificação de caminhos didáticos e pedagógicos. Assim, é necessário considerar o âmbito pedagógico tão importante quanto o âmbito científico, em que o exercício de ser professor não pode ser considerado uma atividade de segundo plano, e sim, uma atividade profissional, para qual existem exigências, habilidades e objetivos. Pimenta e Anastasiou (2010, p. 71) relacionam quatro saberes necessários a essa formação, são eles: 


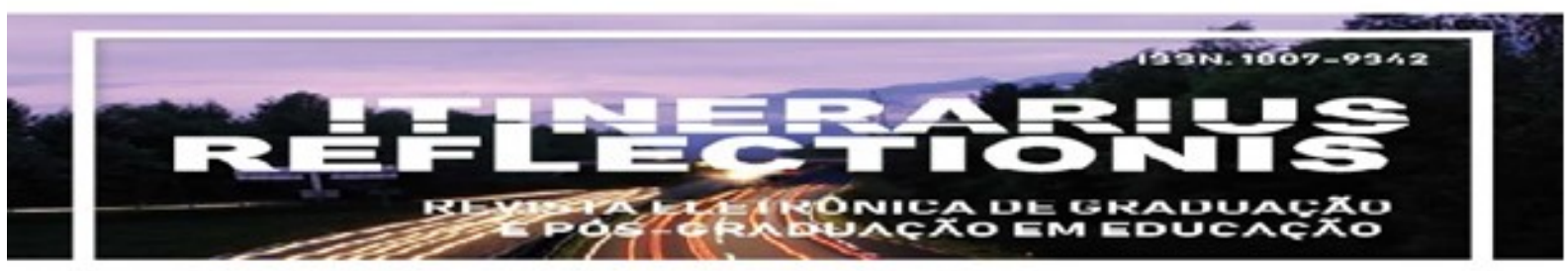

Volume, 15, número 1, ano 2019

- Saberes das áreas de conhecimento: ninguém ensina o que não sabe;

- Saberes pedagógicos: pois o ensinar é uma prática educativa que tem diferentes e diversas direções de sentido na formação do humano;

- Saberes didáticos: que tratam da articulação da teoria da educação e da teoria do ensino para ensinar nas situações contextualizadas;

- Saberes da experiência do sujeito professor: que dizem do modo como nos apropriamos do ser professor em nossa vida. (PIMENTA E ANASTASIOU, 2010, p. 71).

A partir do questionamento sobre o que é ser professor, os participantes da pesquisa expressaram que:

Quadro 1 - O que é ser professor para você?

\begin{tabular}{|l|l|}
\hline Professor 1 & Ser norteador e incentivador. \\
\hline Professor 2 & Ensinar disponibilizando saber, extensão e pesquisa. \\
\hline Professor 3 & Desafio. \\
\hline Professor 4 & $\begin{array}{l}\text { É ser uma pessoa transformadora, que ensina e aprende, que busca levar os } \\
\text { discentes ao conhecimento. }\end{array}$ \\
\hline Professor 5 & Um herói. \\
\hline Professor 6 & Conquista da carreira planejada (fazer o que gosta). \\
\hline Professor 7 & É conseguir despertar o senso crítico e o desejo de aprender do aluno. \\
\hline Professor 8 & Educador e pesquisador. \\
\hline Professor 9 & $\begin{array}{l}\text { Ser não apenas instrumento de transmissão de conhecimentos específicos, mas } \\
\text { sim educadores que auxiliem positivamente também na formação do caráter de } \\
\text { cada aluno/cidadão. }\end{array}$ \\
\hline Professor 10 & Primo: um formador de mão de obra especializada, secundo: formador de caráter. \\
\hline Professor 11 & $\begin{array}{l}\text { Ter uma nobre missão que é formar profissionais e cidadãos para o mercado de } \\
\text { trabalho. }\end{array}$ \\
\hline Professor 12 & $\begin{array}{l}\text { Ser perseverante; acreditar e gostar muito daquilo que se faz; ter muito equilíbrio } \\
\text { emocional para suportar as diversidades; ter bom embasamento teórico para } \\
\text { abordar os assuntos com clareza, profundidade e responsabilidade. }\end{array}$ \\
\hline Professor 13 & Auxiliar na transmissão e na geração de conhecimento. \\
\hline Professor 14 & Meu trabalho. \\
\hline Professor 15 & Formar pessoas quanto a aspectos profissionais e interpessoais. \\
\hline Professor 16 & Contato na transmissão do conhecimento. \\
\hline Professor 17 & Realização de um sonho, após muita luta. \\
\hline Professor 18 & Poder ensinar. \\
\hline
\end{tabular}

Fonte: Os autores (2017) 


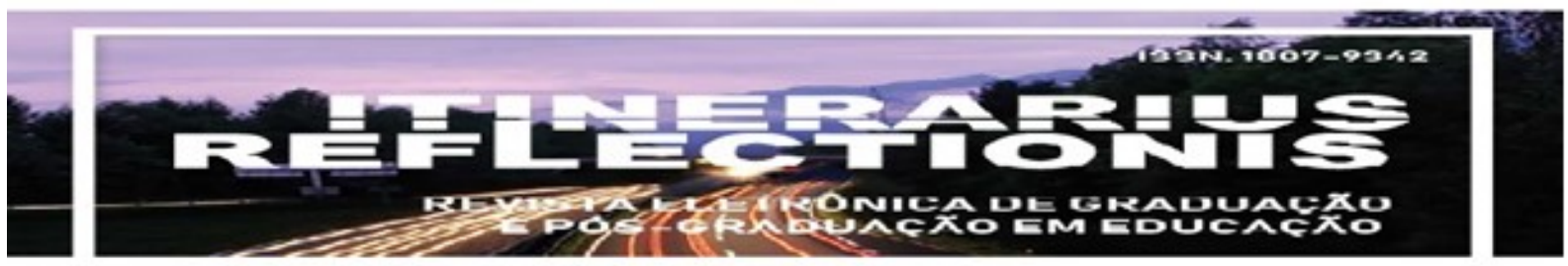

Volume, 15, número 1, ano 2019

Ser professor envolve, muitas vezes, as funções de docência; de pesquisa, de extensão e de administração. Os diversos papéis do professor ocupam uma pertinente representatividade na carreira docente, desde que haja a compreensão do valor e das necessidades de cada função.

A docência é responsável pelo ensino, que segundo Zabalza (2004) deveria ser a mais importante, por representar a condição formativa da universidade. A docência é uma atividade profissional que sofreu algumas mudanças ao longo da reforma das universidades, em que busca alcançar outros objetivos e exigências. Dentre esses objetivos e exigências, está o planejamento e o processo de ensino-aprendizagem, responsável pela formação e pela construção de conhecimentos. A condução de um processo de ensino-aprendizagem não é uma transmissão de conhecimentos e nem uma atividade desenvolvida sem planejamentos.

Nas considerações de Masetto (2012),

O mais grave (ainda hoje, em muitas faculdades e universidades brasileiras) diz respeito ao seguinte: não se tem consciência na prática [em sala de aula] de que a aprendizagem dos alunos é objetivo central dos cursos de graduação e que nosso trabalho de docentes deve privilegiar não apenas o processo de ensino, mas o processo de ensino-aprendizagem, em que a ênfase esteja na aprendizagem dos alunos e não na transmissão de conhecimentos por parte dos professores. (MASETTO, 2012, p.10).

Nessa perspectiva, analisando as respostas dos professores, colaboradores da pesquisa, destaca-se as concepções: "Ter uma nobre missão que é formar profissionais e cidadãos para o mercado de trabalho" (Professor 11); "Auxiliar na transmissão e na geração de conhecimento" (Professor 13); "Contato na transmissão do conhecimento" (Professor 16), ainda permeiam no ensino universitário, no qual o processo de ensino-aprendizagem e a formação do sujeito relacionam-se com transmissão de conhecimentos, e não com a construção de conhecimentos, e ainda, estão voltados somente para o mercado de trabalho, ao invés de um aperfeiçoamento educacional e pessoal do indivíduo. 


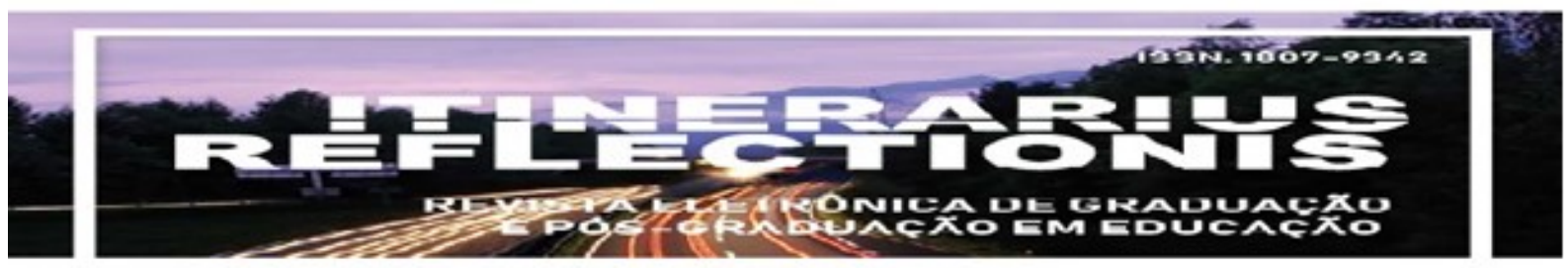

Volume, 15, número 1, ano 2019

Apesar disso, com as mudanças na universidade, abre-se lugar para as "novas" concepções e perspectivas a respeito do processo de ensino-aprendizagem e formação, em que as considerações em ser professor são: "É ser uma pessoa transformadora, que ensina e aprende, que busca levar os discentes ao conhecimento" (Professor 4); "É conseguir despertar o senso crítico e o desejo de aprender do aluno" (Professor 7); "Formar pessoas quanto à aspectos profissionais e interpessoais" (Professor 15).

Como fundamenta Zabalza (2004, p. 110) "[...] A tradicional missão do docente como transmissor de conhecimentos ficou relegada a segundo plano, dando espaço ao seu papel como facilitador da aprendizagem de seus alunos", refletindo que existem muitos caminhos de acesso ao conhecimento, porém cabe ao professor trabalhar na ação de aprendizagem.

O ensino caminha para outros rumos, no qual almeja-se uma formação fundamentada e o acesso ao mundo do conhecimento, sem restrições e transmissões, focando cada vez mais nas construções e descobertas. Enricone (2006, p. 14) discute sobre "[...] a metodologia do aprender que exige conhecimento na área cognitiva e reconhecimento de que o aluno é o sujeito responsável pela aprendizagem", em que o aprendizado pode ser orientado de diversas formas, dependendo dos objetivos do professor.

Todos esses aspectos e considerações trazidos pelos professores, caracterizam sua identidade e seu perfil, esclarecendo as ações e práticas desenvolvidas ao longo da carreira docente. As concepções dos docentes influenciam em cada planejamento e atividade educacional, estando presente o perfil que cada um adota.

A ênfase na identidade e no perfil dos professores, juntamente com as concepções, interferem tanto no processo de ensino-aprendizagem como na formação dos sujeitos, sendo um ponto chave e característico da docência universitária.

\section{A FORMAÇÃO DOS DISCENTES NO ÂMBITO UNIVERSITÁRIO}




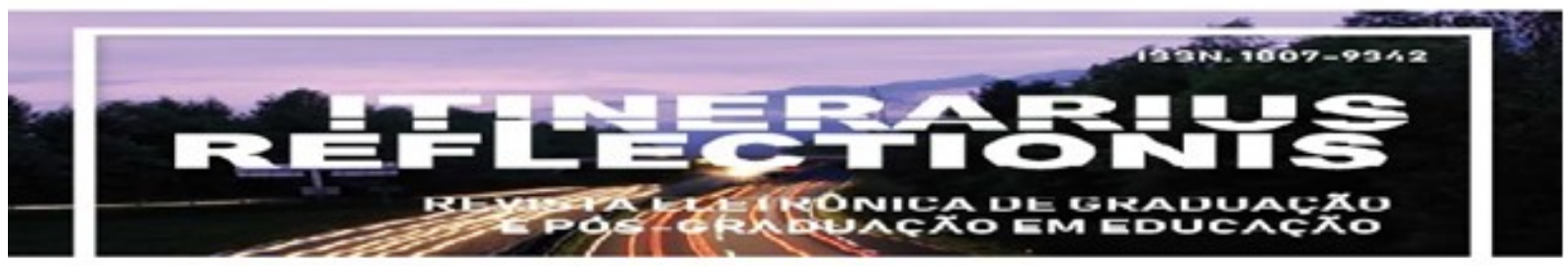

Volume, 15, número 1, ano 2019

Ser professor não pode se restringir ao ensinar, sua atuação vai além do espaço da sala de aula e, por isso, sua formação deve permitir uma atuação consciente em todos os espaços educacionais. Na concepção de García (1999, p.26), a formação de professores "é uma área do conhecimento e investigação que se centra no estudo dos processos através dos quais os professores aprendem e desenvolvem a sua competência profissional".

A formação dos discentes é construída a partir de aspectos teóricos, práticos e pedagógicos, ao longo do processo de ensino-aprendizagem e construção de conhecimentos, mediados pelo professor. As ações de aprendizagem e reflexão desenvolvidas ao longo da formação dos sujeitos são capazes de transformar ideias e práticas, a respeito da área de atuação.

A formação vai além de adquirir informações ou desenvolver novas habilidades, segundo Zabalza (2004, p. 39): "A importância da formação deriva, a meu ver, de sua necessária vinculação ao crescimento e aperfeiçoamento das pessoas, aperfeiçoamento que tem de ser entendido em um sentido global: crescer como pessoas". Com isso, a atuação e os reflexos da identidade e do perfil dos professores é que mediam esse processo pertinente para o crescimento e aperfeiçoamento do sujeito.

O processo de formação envolve muitas construções que se desenvolvem ao longo das atividades educacionais. Além do crescimento e aperfeiçoamento dos indivíduos estão novas possibilidades de atuação pessoal, a construção de novos conhecimentos, a formação de atitudes e concepções, o aperfeiçoamento de habilidades, a contribuição de atividades práticas e a construção de novos comportamentos.

Para tanto, alguns aspectos influenciam nesse processo e são pertinentes para alcançar as construções da formação no âmbito universitário, dentre eles estão a condução, o desenvolvimento e as atividades educacionais das aulas dos professores; o processo de ensino e aprendizagem, a avaliação, o trabalho com as dificuldades e os "erros" dos alunos. 


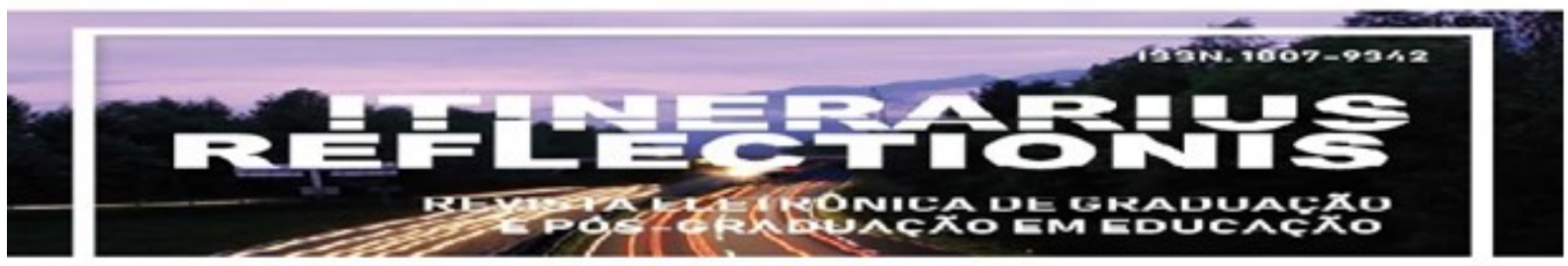

Volume, 15, número 1, ano 2019

A aprendizagem na visão do aluno pode ser facilmente distorcida pela atuação do professor. Neste aspecto, Enricone (2006, p.14) menciona que a ênfase ainda tem sido depositada no ensino como transmissão ou comunicação oral de temas pelos professores. Zabalza (2004, p.207), ao abordar os estudantes universitários, menciona que a aprendizagem para eles é "um processo de acumulação de conhecimentos; um processo de memorizar e reproduzir; a capacidade de aplicação de conhecimentos; dar sentido e significado a algo; interpretar e entender a realidade; um processo de desenvolvimento pessoal".

$\mathrm{Na}$ contramão do que venha a ser uma "boa" aula, ainda encontra-se nas instituições professores que não demonstram ter em suas aulas o compromisso com a aprendizagem significativa dos seus alunos, com predomínio do instrucionismo, no qual o aluno é objeto da instrução, prevalecendo a reprodução, com a produção de conhecimentos superficiais, alunos passivos sem autonomia e que esperam o saber, exercendo um trabalho intelectual de espera.

Neste cenário, percebe-se que os professores têm muito que aprender e têm muito a ensinar. Sobre o potencial da aprendizagem, Enricone (2006) menciona:

O aprender a aprender parte da descoberta da relevância do aprendido e do conhecimento da capacidade de aprendizagem. É um produto de um processo complexo que depende de pesquisa docente, de cultura experiencial, da introdução de inovações no fazer pedagógico. Tudo isso tem a ver com o aprender a aprender para aprender a ensinar. (ENRICONE, 2006, p.16).

Uma "boa" aula é aquela que tem o compromisso com a aprendizagem, que é planejada de forma contínua e flexível, que desperta o interesse dos alunos para a pesquisa, para a construção do seu próprio conhecimento, que é atraente, que estabelece conexões com o cotidiano do aluno, que semeia questionamentos, debates, que favorece o pensamento crítico, que trabalha a dimensão humana, visando o pessoal e social, que estimula o aprender junto, mobilizando e motivando os alunos que, em sua diversidade, possuem variadas necessidades de aprendizagem. 


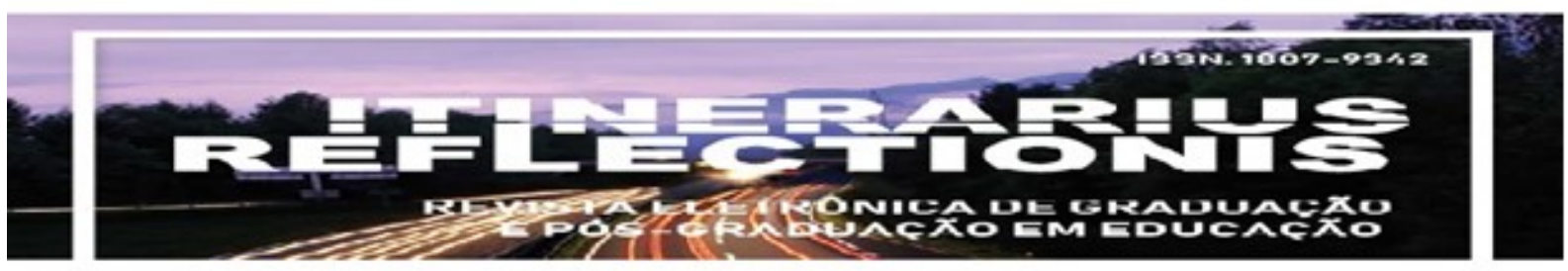

Volume, 15, número 1, ano 2019

Para Pedrini (2018):

A intencionalidade do ensino e aprendizagem recai sobre o planejamento e sistematização do conhecimento em processos que serão desenvolvidos no âmbito da aula. Considera o aluno, pois é o sujeito de um propósito educacional. A não redução à didática e às metodologias extrapola as delimitações da sala de aula, o lugar mais comum da prática pedagógica. (PEDRINI, 2018, p. 51-52).

E ainda, segundo Pedrini (2018, p. 58) "A rotina da aula exige que o professor tenha o interesse constante em compreender e ter empatia pelo aluno. Atrela-se a isso a falta de habilidades e competências dos alunos para se compreender e articular conceitos." Assim, uma "boa" aula é o cruzamento de três frentes: a primeira diz respeito ao professor (ensino), a segunda é constituída pelo conteúdo em si e a terceira diz respeito aos alunos (aprendizagem).

Ao considerarmos as aulas ministradas pelos professores universitários, questionamos aos participantes da pesquisa sobre as concepções deles do que vem a ser uma "boa" aula e sobre o que deveria ser privilegiado em suas aulas, e os participantes responderam:

Quadro 2 - O que é uma "boa" aula para você?

\begin{tabular}{|c|l|}
\hline Professor 1 & $\begin{array}{l}\text { Aquela em que eu saio com dúvidas, pois fui questionado exaustivamente pelos } \\
\text { alunos. Ou aquela em que não passo dos slides iniciais, pois as discussões geradas } \\
\text { são muito mais produtivas do que toda a programação adiante. }\end{array}$ \\
\hline Professor 2 & Bom conteúdo que os alunos compreendam. \\
\hline Professor 3 & $\begin{array}{l}\text { Boa aula deve ser aquela em que consigo despertar o interesse dos alunos sobre o } \\
\text { conteúdo. Paciência. }\end{array}$ \\
\hline Professor 4 & $\begin{array}{l}\text { É aquela em que os discentes ficaram empolgados, participaram, fizeram críticas } \\
\text { do conteúdo apresentado. Deve-se privilegiar o conteúdo a ser ministrado e o } \\
\text { tempo, junto com as ferramentas estratégicas que levarão os discentes a ficarem } \\
\text { motivados. }\end{array}$ \\
\hline Professor 5 & $\begin{array}{l}\text { Transmitir o conhecimento e estimular o raciocínio dos alunos para sua evolução } \\
\text { individual. }\end{array}$ \\
\hline Professor 6 & Aquela que prende a atenção dos alunos. Privilegiar a parte prática \\
\hline Professor 7 & $\begin{array}{l}\text { Uma aula que dispõe de recursos sejam tecnológicos ou orais, para despertar a } \\
\text { curiosidade e o desejo de aprofundar o conhecimento. }\end{array}$ \\
\hline Professor 8 & Deve incentivar a discussão e o questionamento. \\
\hline Professor 9 & Conteúdo e didática. \\
\hline
\end{tabular}




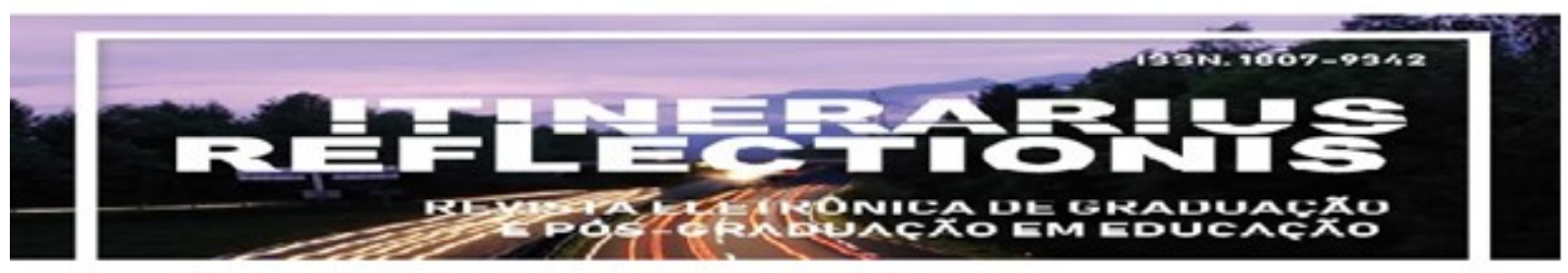

Volume, 15, número 1, ano 2019

\begin{tabular}{|c|l|}
\hline Professor 10 & $\begin{array}{l}\text { Aquela em que conseguimos transmitir os conteúdos de maneira clara e que os } \\
\text { alunos demonstram ter adquirido conhecimento satisfatório ao final da mesma. } \\
\text { Facilitar a aprendizagem dos discentes. }\end{array}$ \\
\hline Professor 11 & $\begin{array}{l}\text { Para qualquer assunto abordado, a boa aula é aquela que prende a atenção do } \\
\text { aluno. Depende do assunto abordado e do ritmo da turma. }\end{array}$ \\
\hline Professor 12 & $\begin{array}{l}\text { Uma boa aula é quando o professor consegue dar significado prático no conteúdo } \\
\text { ministrado, que vai ser útil para sua futura profissão. }\end{array}$ \\
\hline Professor 13 & $\begin{array}{l}\text { Quando o docente consegue atrair a atenção dos discentes e motivá-los a buscar o } \\
\text { conhecimento. Momento em que os discentes sinalizam pelo interesse em } \\
\text { apreender o conteúdo, compartilham experiência e ficam atentos durante todo o } \\
\text { tempo sem achar cansativa e entediante a aula. }\end{array}$ \\
\hline Professor 14 & $\begin{array}{l}\text { Uma aula que apresente os conteúdos de forma significativa e compreensível para } \\
\text { os alunos. Por isso, o professor deve privilegiar aspectos aplicados do conteúdo } \\
\text { nas aulas, buscando aproximá-los da realidade dos alunos. }\end{array}$ \\
\hline Professor 15 & $\begin{array}{l}\text { Uma boa aula é aquela em que o aluno consegue contextualizar o conhecimento } \\
\text { dele com aquilo que está sendo apresentado em sala. O professor deve privilegiar } \\
\text { a aprendizagem. É importante o docente adequar o conhecimento ao público, } \\
\text { tornando o processo ensino-aprendizado interessante. }\end{array}$ \\
\hline Professor 16 & Motivacional e que desperta a curiosidade e interesse. Boa didática. \\
\hline Professor 17 & $\begin{array}{l}\text { Objetiva com a contextualização de problemas práticos que os discentes poderão } \\
\text { se deparar no dia a dia profissional. }\end{array}$ \\
\hline Professor 18 & Quando o professor ensina e os alunos aprendem. \\
\hline
\end{tabular}

Fonte: Os autores (2017)

Em busca de formar uma única voz docente para apresentar o que deve ser privilegiado em uma "boa" aula, destaca-se algumas palavras das respostas dos participantes: paciência, conteúdo, tempo, prática, discussões, questionamentos e didática.

As concepções sobre os aspectos das aulas dos professores e a condução das atividades educacionais se expressam em pontos de vistas diferentes. Percebe-se que alguns deles consideram relevante a questão pedagógica e didática: "Uma boa aula é aquela em que o aluno consegue contextualizar o conhecimento dele com aquilo que está sendo apresentado em sala. O professor deve privilegiar a aprendizagem. É importante o docente adequar o conhecimento ao público, tornando o processo ensino-aprendizado interessante" (Professor 15), ao passo que outros privilegiam a instrução e a transmissão dos conhecimentos: "Aquela em que conseguimos transmitir os conteúdos de maneira clara e que os alunos demonstram ter adquirido conhecimento satisfatório ao final da mesma" (Professor 10). 


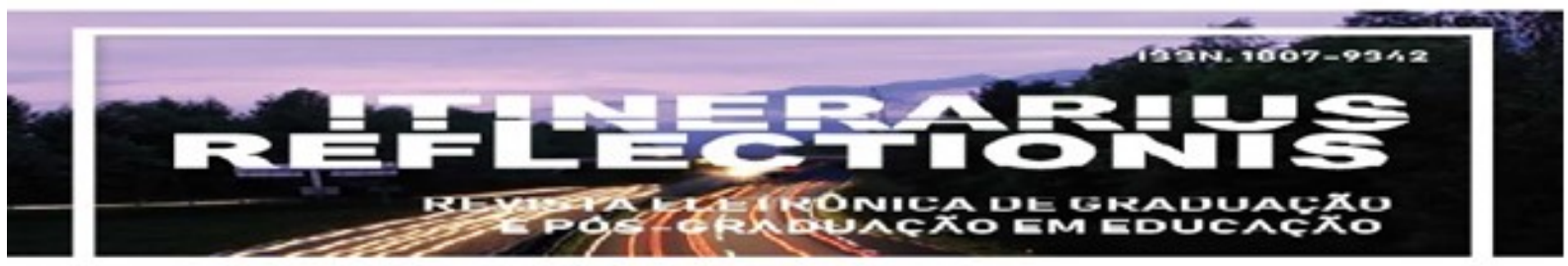

Volume, 15, número 1, ano 2019

Nesse sentido, reflete-se que apesar dos programas de formação, das pesquisas acadêmicas e dos trabalhos desenvolvidos em teses e dissertações, ainda existe a concepção da aula instrucional e do processo de ensino e aprendizagem a partir da transmissão de conhecimentos.

Segundo Gil (2009),

Ocorre aprendizagem quando uma pessoa manifesta aumento da capacidade para determinados desempenhos em decorrência de experiências por que passou. Também se pode dizer que ocorre aprendizagem quando, em virtude da experiência, uma pessoa manifesta alterações de disposições, tais como atitudes, interesses ou valores. (GIL, 2009, p. 57).

O processo de ensino-aprendizagem é mais complexo do que uma simples instrução ou transmissão de conhecimentos, vai além de decorar conteúdos e desenvolver um raciocínio lógico padronizado. A aprendizagem contextualizada se identificada na construção de conhecimentos, no crescimento e aperfeiçoamento do sujeito, chegando à vivência de novas experiências e na edificação de atitude, valores e posturas.

Além disso, considerar as diferenças entre os indivíduos, o contexto da realidade, a motivação, o interesse, a participação, as contribuições, a atenção e o feedback, são ações que fazem parte do processo de ensino-aprendizagem e que precisam ser alcançadas, tanto para a aprendizagem quanto para uma "boa" aula.

Nesse contexto, Severino (2008, p. 13) destaca que: "Na Universidade, a aprendizagem, a docência, a ensinagem, só serão significativas se forem sustentadas por uma permanente atividade de construção de conhecimentos. Tanto quanto o aluno, o professor precisa da pesquisa para bem conduzir um ensino eficaz." Assim, as atividades educacionais desenvolvidas e planejadas pelo professor influenciam no processo de ensino-aprendizagem, em que sua postura investigativa e a constante busca pela construção do conhecimento se fortalecem na pesquisa e nas situações de estudo. 


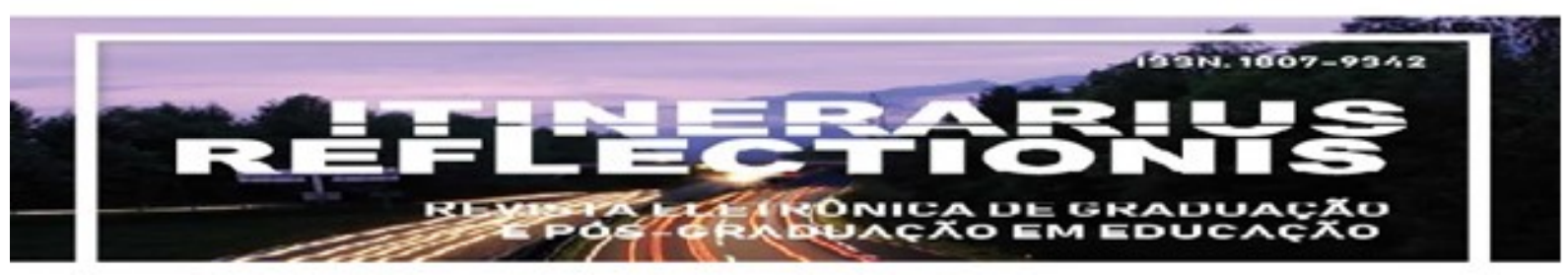

Volume, 15, número 1, ano 2019

Outro aspecto que influencia nas construções da formação é a avaliação. Avaliar continua sendo um processo nada fácil para os professores. Na universidade, percebe-se facilmente o predomínio da prática avaliativa tradicional, em que a nota é consequência e não motivação para os estudos.

Baseado em Mendes (2005), somos levados a refletir sobre qual prática avaliativa é utilizada de fato na Educação Superior, isto é, se avaliamos ou se apenas verificamos os resultados obtidos pelos nossos alunos. Para a autora, o que acontece na maioria das vezes é apenas a verificação da aprendizagem, a verificação dos acertos e não há quase nenhuma atenção aos erros.

Refletindo sobre a atuação do professor, mantendo o foco na aprendizagem e na formação, questionamos os participantes da pesquisa sobre como eles verificavam se os seus alunos tinham aprendido o conteúdo apresentado por eles.

Quadro 3 - Como você verifica se seu aluno aprendeu o conteúdo apresentado?

\begin{tabular}{|l|l|}
\hline Professor 1 & $\begin{array}{l}\text { Quando ele(a) consegue contextualizar um conhecimento ou ter um pensamento } \\
\text { lógico. }\end{array}$ \\
\hline Professor 2 & Prova e discussão do tema. \\
\hline Professor 3 & Exercícios, trabalhos e avaliações. \\
\hline Professor 4 & $\begin{array}{l}\text { Por meio de relatórios, participações em aula, teste sobre os conteúdos } \\
\text { apresentados, exemplos práticos dos conteúdos nas apresentações. }\end{array}$ \\
\hline Professor 5 & Por sua expressão em aula/prova e perguntas em sala de aula. \\
\hline Professor 6 & Por meio do sistema tradicional de verificação: avaliações escritas. \\
\hline Professor 7 & Prova. Conversas. \\
\hline Professor 8 & Através de questionamentos dirigidos a eles, avaliações, etc. \\
\hline Professor 9 & Por meio de avaliações periódicas, "provas". \\
\hline Professor 10 & $\begin{array}{l}\text { Quando o aluno interage com o professor e consegue discutir questões teórico- } \\
\text { práticas da disciplina. }\end{array}$ \\
\hline Professor 11 & $\begin{array}{l}\text { Pelo nível das perguntas e questionamentos e quando vão bem na avaliação, } \\
\text { respondendo as questões com coerência, mesmo sem aprofundar muito no tema. }\end{array}$ \\
\hline Professor 12 & $\begin{array}{l}\text { Avaliações escritas, perguntas durante as aulas, relatórios, testes semanais na } \\
\text { plataforma Moodle. }\end{array}$ \\
\hline Professor 13 & $\begin{array}{l}\text { Avaliações formais como "provas e trabalhos" e avaliações informais pelos } \\
\text { comentários e perguntas feitas em sala pelos alunos. }\end{array}$ \\
\hline Professor 14 & Por meio de avaliação teóricas-práticas. \\
\hline
\end{tabular}




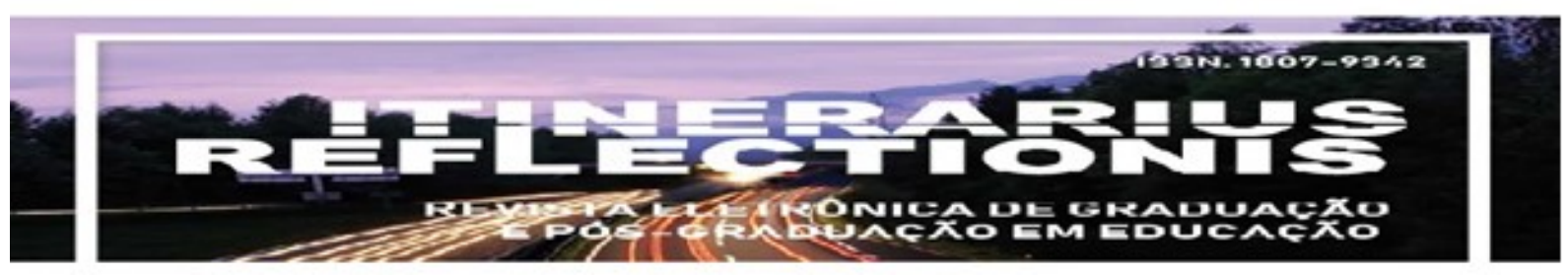

Volume, 15, número 1, ano 2019

\begin{tabular}{|l|l|}
\hline Professor 15 & Pelas perguntas no decorrer e respostas na avaliação que são de raciocínio. \\
\hline Professor 16 & $\begin{array}{l}\text { Além de avaliações escritas, os alunos apresentam e respondem perguntas sobre } \\
\text { artigos científicos dos temas da disciplina. }\end{array}$ \\
\hline Professor 17 & $\begin{array}{l}\text { A avaliação se dá por meio da verificação das respostas na avaliação escrita e das } \\
\text { respostas em seu seminário (artigo científico) e aos problemas práticos levantados } \\
\text { em sala de aula. }\end{array}$ \\
\hline Professor 18 & Prova. \\
\hline
\end{tabular}

Fonte: Os autores (2017)

Baseandos nas respostas dos participantes, verifica-se que a maioria sustenta as provas (avaliações) na forma de verificação da aprendizagem, como pode ser visto na resposta do Professor 6; do Professor 9; do Professor 14 e do Professor 18. Alguns professores as colocaram como único meio de análise da aprendizagem, realizadas em tempos e espaços específicos, já outros mencionaram também a necessidade de complementação através de discussões, participações, interações, etc., podendo ser visto na expressão do Professor 3; do Professor 4; do Professor 5; do Professor 8; do Professor 12 e do Professor 16.

O uso da verificação de aprendizagem é observado em todos os níveis de ensino e é uma realidade que devemos colocar em pauta nos diálogos universitários com o intuito de refletir em relação às possibilidades e às mudanças urgentes sobre as práticas avaliativas da Educação Superior. A avaliação deve acontecer durante todo o processo de ensinoaprendizagem de maneira contínua e formativa.

Fundamentados em Mendes (2005), faz-se necessário eliminar o uso autoritário da avaliação, onde ela é vista como castigo e a nota como instrumento de coerção. É preciso ter uma metodologia diversificada pautada no diálogo e promover o redimensionamento do uso da avaliação, visto que nota classifica aluno e não diagnostica a realidade avaliada. $\mathrm{O}$ mais pertinente é a modificação da postura diante dos resultados e criação de uma nova mentalidade, em favor de novas práticas avaliativas.

A avaliação é uma prática para auxiliar o professor sobre a aprendizagem dos alunos, se há dificuldades, se houve a construção de conhecimentos e se os conteúdos foram 


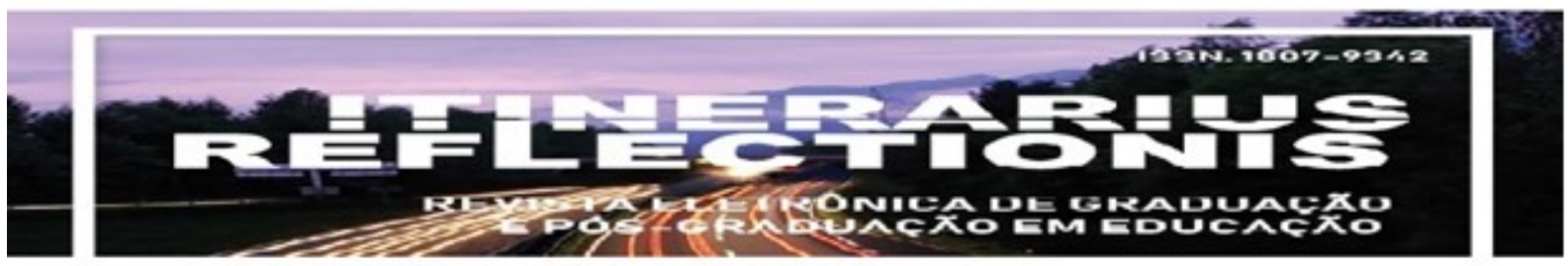

Volume, 15, número 1, ano 2019

aprendidos de maneira contextualizada. Ao contrário de algumas posturas, a prática avaliativa traz subsídios ao professor para dar prosseguimento ou mudanças no processo de ensino e aprendizagem, visando a formação do sujeito.

O processo avaliativo está entre as categorias do trabalho pedagógico, sendo um instrumento que faz parte do cotidiano do professor, ou seja, utilizado de maneira constante, seja por meio de relatórios; observações; questionamentos aos sujeitos; atividades educacionais e "provas", porém se manifestando de várias formas em todos os momentos educacionais.

De acordo com Freitas:

Para uma visão linear do processo pedagógico, o planejamento didático é uma sucessão de etapas que começa com a definição dos objetivos do ensino, passa pela definição do conteúdo e dos métodos, pela execução do planejamento e finalmente pela avaliação do estudante. A avaliação alimenta o processo dando dicas ao professor e ao aluno sobre o que foi ensinado e aprendido. (FREITAS et. al., 2014, p. 14).

Para um trabalho pedagógico contextualizado, as etapas descritas pelos autores são pertinentes e cada uma assume um papel no processo de ensino e aprendizagem. A posição da avaliação está em cada atividade educacional, com o objetivo de priorizar a aprendizagem dos indivíduos.

A questão das dificuldades dos alunos em alguns conteúdos e da reprovação pode estar vinculada tanto com a prática pedagógica do professor quanto ao planejamento do processo de ensino-aprendizagem. Os conhecimentos prévios dos alunos e as organizações de estudos também influenciam nessas condições, porém o julgamento de não aprendizado do sujeito não pode estar associado apenas com compromisso e dedicação, há aspectos mais relevantes por trás dessa situação.

Diante disso, destaca-se a relevância da avaliação constante, nas aulas, pois ela é capaz de revelar situações que podem ser evitadas e afastar a ideia de reprovação. Segundo Severino (2008, p. 27), "O docente sempre corre o risco de transformar sua intervenção numa 


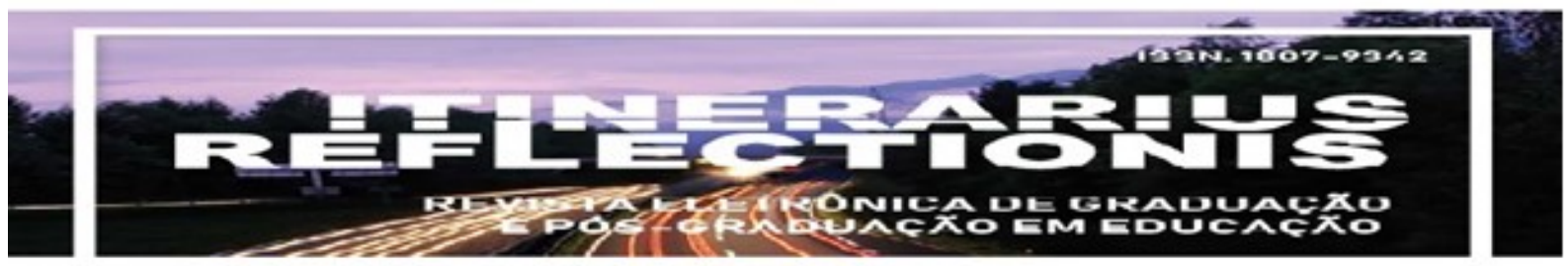

Volume, 15, número 1, ano 2019

mera operação técnica de mediação ou então num severo julgamento moral, capaz de provocar uma estigmatização do aluno (...)", distanciando-se do sentido da atuação docente enquanto avaliador, que é uma análise diagnóstica com o objetivo de identificar aspectos positivos e negativos, para então desenvolver uma orientação educacional destinada ao sujeito.

A mediação do professor é pertinente nas situações de estudo e na aprendizagem dos sujeitos, considerando que trabalhar com diversas organizações de ensino afasta a ideia de reprovação. Porém, a questão de avaliação e reprovação distorce tanto nos conceitos dos professores como nos dos alunos, sendo necessária a construção de uma nova visão sobre esses aspectos. Uma visão de que a avaliação é uma ferramenta para identificar as dificuldades dos sujeitos, para refletir novas formas de trabalhos e planejamentos, uma mediação para a formação, e não um instrumento que pode induzir a reprovação.

Nesse sentido, as dificuldades e os "erros" dos alunos devem se transformar em situações desencadeadoras de reflexões e discussões, como destaca Hoffmann (2009), trazendo para o processo educativo novas aprendizagens, mediante a essas constatações e afastando cada vez mais das reprovações. As constatações das dificuldades e dos "erros" dos alunos, a partir da avaliação, têm a função de proporcionar ao professor uma nova situação para reaver seu planejamento e direcionar de uma outra forma a situação de aprendizagem.

O erro que o aluno comete, ao realizar alguma atividade avaliativa ou não, deve ser enxergado não como algo negativo, mas como uma revelação positiva de grande significação pedagógica. $\mathrm{O}$ professor diante da situação do erro deve adotar uma postura para o encaminhamento da descoberta do processo que levou o aluno ao erro e baseado nessa compreensão, poderá corrigi-lo.

Todos esses aspectos estão intrinsecamente ligados à formação, em que o desenvolvimento de cada um, atividades educacionais, processo de ensino-aprendizagem, 


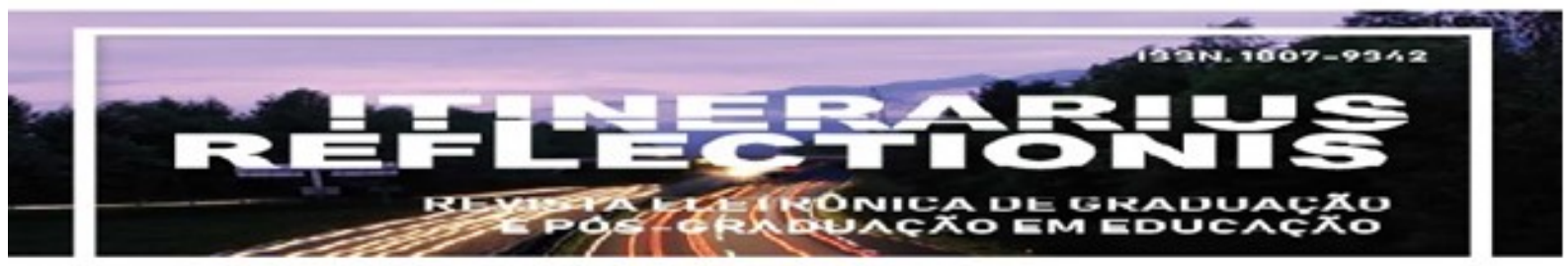

Volume, 15, número 1, ano 2019

avaliação, o trabalho com as dificuldades e os "erros" dos alunos, influenciam no crescimento do sujeito.

\section{CONSIDERAÇÕES FINAIS}

A docência universitária trabalha aspectos que envolvem tanto a influência da identidade e perfil do professor, quanto funções ligadas à formação do sujeito. Todos esses pontos são fatores diretamente interconectados nas expressões: das concepções e a atuação dos professores, do processo de ensino-aprendizagem, da construção de conhecimentos, do crescimento e aperfeiçoamento dos sujeitos.

O professor universitário além de ser "a peça-chave" para o encaminhamento do processo de formação, ele exerce diversas funções entre ser o mediador, e também, o motivador do processo de ensino-aprendizagem. Esses papéis desempenhados pelo professor exercem uma valorosa influência no desenvolvimento e aperfeiçoamento do sujeito, enquanto aluno, profissional e ser social.

Nesse sentido, investigar, analisar e discutir sobre a identidade e perfil dos professores da Educação Superior, se torna pertinente para compreender e avaliar as finalidades da docência e o processo de formação acadêmica. A identidade e o perfil dos professores são características que definem suas atuações e que propagam suas concepções, ideias e práticas de trabalho, sendo aspectos primordiais no âmbito educacional.

Diante dos objetivos e do problema de pesquisa que pautam sobre a identidade e perfil dos professores universitários, que atuam no curso de Agronomia da Universidade Federal de Uberlândia, Campus Monte Carmelo, a partir de uma perspectiva didáticopedagógica, conjectura-se que todos os professores envolvidos na pesquisa apresentam formações qualificadas em sua área de atuação, sendo que a maioria são iniciantes na carreira universitária e já participaram de cursos de formação e atualização docente, focando o aspecto pedagógico. Apesar disso, alguns apresentam em suas respostas manifestações de ideias que 


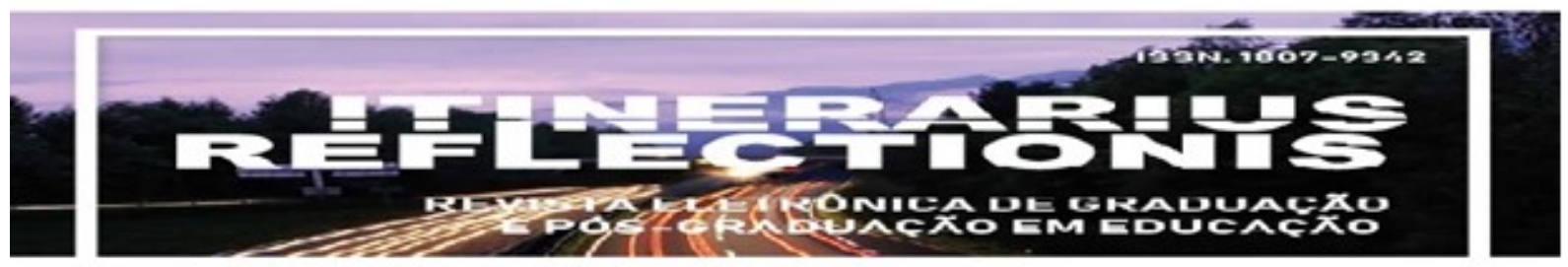

Volume, 15, número 1, ano 2019

lhes são próprias, tornando nítidas as marcas da identidade e do perfil desses profissionais e, com isso, recomenda-se a continuidade do estudo dessa temática.

$\mathrm{Na}$ análise das respostas dos colaboradores da pesquisa, percebe-se que ainda existem professores que exercem tal profissão, mas que se consideram em uma outra classificação no exercício de suas atividades, as de origem do curso de formação, centrada no âmbito científico, como por exemplo, "engenheiros". É um tanto preocupante pensar que professores, exercendo essa profissão, não se classifiquem como tal, e com isso reflete-se, como se dá o desenvolvimento de uma prática pedagógica e profissional diante desse conflito?

Conforme abordado na pesquisa, o âmbito pedagógico é tão importante quanto o âmbito científico, e é nesse sentido que chamamos a atenção para o perfil e identidade dos professores, mediante a consideração de que para se chegar a um processo de formação que proporcione aperfeiçoamento educacional e social ao sujeito, é preciso interligar esses aspectos, que dizem respeito às atuações dos docentes universitários.

O exercício da função de professor envolve a responsabilidade pelo ensino, mas também abrange a pesquisa, a extensão e as inerentes ao exercício de direção, assessoramento, chefia, coordenação e assistência na própria instituição, além daquelas previstas em legislação específica, de acordo com a Lei $\mathrm{n}^{\circ} 12.772$, de 28 de dezembro de 2012. Todas as funções desempenhadas pelos professores universitários são pertinentes e, muitas vezes, interligam-se no desenvolvimento de ações educacionais.

Nas respostas dos professores, sujeitos da pesquisa, identifica-se que ainda há a concepção de que "ser professor" está ligado à transmissão de conhecimentos, em ser um profissional que leve os discentes ao conhecimento, um formador de profissionais e cidadãos somente para o mercado de trabalho. A função em "ser professor" vai além de uma mera representação, ela precisa estar associada a um contexto educacional fundamentado e construído tanto pelos alunos, como pelos professores, pautando-se na participação ativa do 


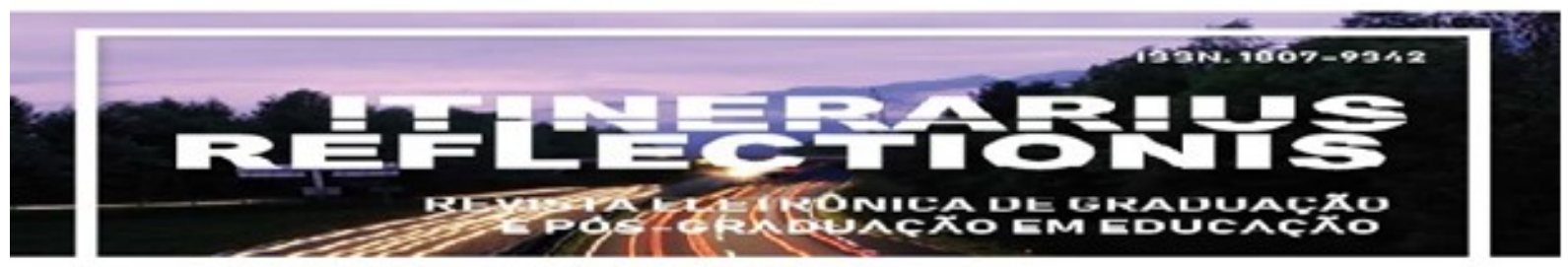

Volume, 15, número 1, ano 2019

indivíduo, na construção de conhecimentos e na reflexão-crítica sobre os diversos temas tratados.

Ao considerar as concepções dos professores universitários sobre o que vem a ser uma "boa" aula, pode-se enfatizar a interação no processo de ensino-aprendizagem entre o professor, o conteúdo e os alunos. O processo de interação entre aluno e professor deve ocorrer de tal maneira que o professor seja um dos elementos mediadores, despertando no aluno a necessidade e o interesse de se envolver em ações educativas. Desta forma, uma aula deve fundamentar-se em metodologias, em práticas pedagógicas, em recursos didáticos e no planejamento teórico e prático que leve em consideração o perfil dos alunos.

Em relação à formação e a profissão docente, na Educação Superior, devemos direcionar nosso olhar para além do conhecimento do conteúdo que o professor ensina. Tão necessários quanto o conhecimento específico da disciplina, são os conhecimentos da forma que se ensina, dos destinatários desse ensino, e da razão que se ensina.

A profissão docente carrega marcas fortes do ser humano, tanto nos destinatários quanto nos agentes, e isso faz com que não seja suficiente ter apenas os saberes pedagógicos, nem tampouco ter apenas os saberes de um determinado conteúdo a ser ensinado. Ao "escutarmos as vozes" dos participantes da pesquisa, percebemos o quão plurais, heterogêneos, personalizados e situados são os saberes docentes, que torna a tentativa de definir uma identidade e um perfil do professor universitário um dilema.

É a articulação dos saberes do conteúdo, dos saberes pedagógicos, dos saberes da experiência e dos saberes culturais que tem o potencial de munir o professor universitário com os mecanismos capazes de propiciar situações de ensino e aprendizagem efetivas. Ao evidenciar a capacidade de avaliar a aprendizagem, percebe-se que para uns ainda prevalecem a utilização de uma única forma avaliativa e, para outros, a maioria, para respirarmos aliviados, encontramos a marca da diversidade, por meio das tradicionais provas, mas também através de discussões, contextualizações, pensamentos, questionamentos etc. 


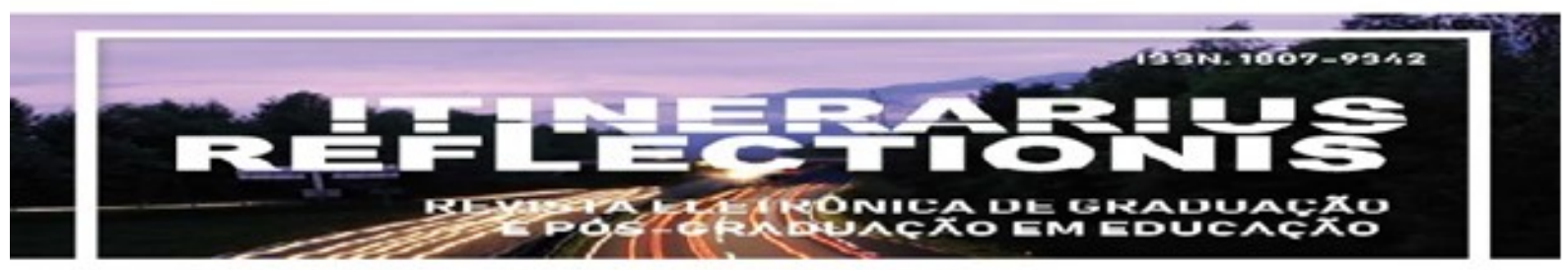

Volume, 15, número 1, ano 2019

Não estamos aqui para criticar a avaliação da aprendizagem por meio do sistema tradicional de verificação - as avaliações escritas - muito pelo contrário, acreditamos ser um meio eficiente de avaliação da aprendizagem, mas desde que acompanhada por outras metodologias, visto que a diversidade é uma característica forte, tanto dos profissionais que ensinam, como dos alunos que aprendem.

As marcas e expressões do professor universitário, desde suas concepções, posturas e planejamentos, articulam sua identidade e perfil, em que há uma grande influência no processo de formação do sujeito, implicando nas construções educacionais e sociais, e com isso, o professor exerce contribuições pertinentes nesse processo de desenvolvimento e aperfeiçoamento do indivíduo.

\section{REFERÊNCIAS BIBLIOGRÁFICAS}

BRASIL. Lei $\mathbf{n}^{\mathbf{0}}$ 12.772, de 28 de dezembro de 2012. Dispõe sobre a estruturação do Plano de Carreiras e Cargos de Magistério Federal. Portal da Legislação: Leis Ordinárias.

Disponível em: http://www.planalto.gov.br/ccivil_03/_ato2011-

2014/2012/lei/L12772compilado.htm. Acesso em: 03 fev. 2019.

ENRICONE, D. A dimensão pedagógica da prática docente futura. In: . (Org.). A docência na Educação Superior: sete olhares. Porto Alegre: Evangraf, 2006. p. 9-28.

FRANCO, M. L. P. B. Análise do Conteúdo. Brasília: Liber Livro Editora, 2007.

FREITAS, L. C. et al. Avaliação educacional: caminhando pela contramão. Petrópolis: Vozes, 2014.

GARCÍA, C. M. Formação de professores para uma mudança educativa. Lisboa: Porto, 1999.

GIL, A. C. Métodos e técnicas de pesquisa social. São Paulo: Atlas, 1999.

GIL, A. C. Metodologia do Ensino Superior. São Paulo: Atlas, 2009. 


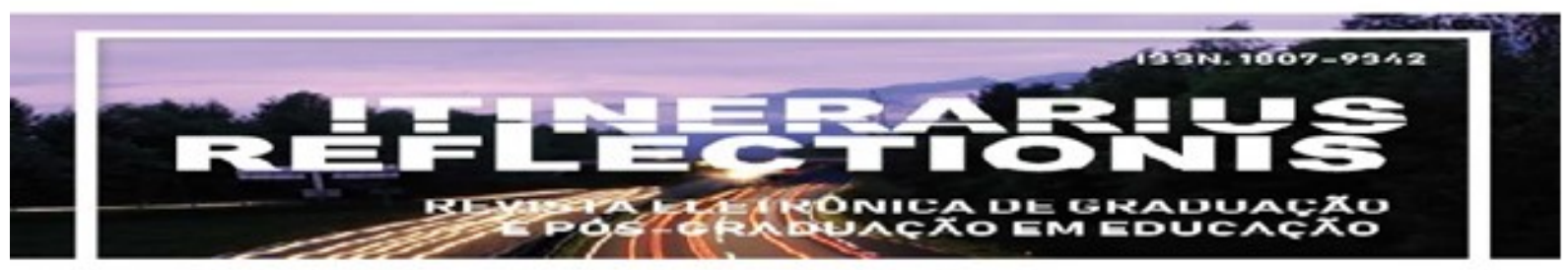

Volume, 15, número 1, ano 2019

GRILLO, M. C. Percursos da constituição da docência. In: ENRICONE, D. (Org.). A docência na Educação Superior: sete olhares. Porto Alegre: Evangraf, 2006. p. 59-72.

GUIMARÃES, V. S. A docência universitária e a constituição da identidade profissional do professor. In: RIBEIRO, M. L; MARTINS, E. de S; CRUZ, A. R. S. da. (Orgs.). Docência no ensino superior: desafios da prática educativa. Salvador: EDUFBA, 2011. p. 15-29.

HOFFMANN, J. Avaliação mediadora: uma prática em construção da pré-escola à universidade. Porto Alegre: Mediação, 2009.

LIBÂNEO, J. C. Pedagogia e pedagogos, para quê? São Paulo: Cortez, 2007.

MALUSÁ, S.; FERREIRA, J. C. B.; PEDRINI, I. A. D. Concepções de docência universitária: ideações sobre a criatividade. Ensino em Re-vista, Uberlândia-MG, v. 23, nº 1 , p. 1-27, 2016.

MASETTO, M. Professor universitário: Um profissional da educação na atividade docente. In MASETTO, M. (Org.). Docência na universidade. $11^{a}$ ed. Campinas-SP: Papirus, 2012. p. 9-28

MENDES, O. M. Avaliação Formativa no Ensino Superior: Reflexões e alternativas possíveis. In: VEIGA, I. P. A; NAVES, M. L. P. (Orgs.). Currículo e avaliação na educação superior. São Paulo: Junqueira \& Marin, 2005. p.175-197.

MINAYO, M. C. S. (Org.). Pesquisa Social: teoria, método e criatividade. Petrópolis: Vozes, 1997.

MINAYO, M. C. S. (Org.). Pesquisa Social: teoria, método e criatividade. Petrópolis: Vozes, 2003.

PEDRINI, I. A. D. Docência universitária: ideações sobre a prática docente de professores atuantes em cursos de Publicidade e Propaganda. 2018. Tese (Doutorado em Educação) Faculdade de Educação, Universidade Federal de Uberlândia - UFU, Uberlândia, 2018.

PIMENTA, S. G.; ANAStASIOU, L. G. C. Docência no Ensino Superior. 4. ed. São Paulo: Cortez, 2010.

ROSSMAN, B. G.; RALLIS, S. F. Learning in the field: an introduction to qualitative research. London: Sage, 1998. 


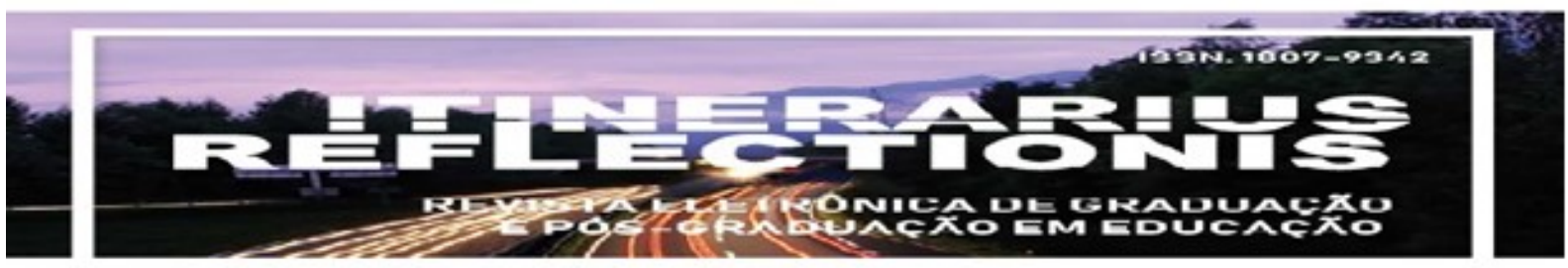

Volume, 15, número 1, ano 2019

SEVERINO, A. J. Ensino e pesquisa na docência universitária: caminhos para a integração. São Paulo: FEUSP, 2008.

ZABALZA, M. A. O ensino Universitário, seus cenários e seus protagonistas. Trad, Ernani Rosa. Porto Alegre: Artmed, 2002.

ZABALZA, M. A. O ensino Universitário: seu cenário e seus protagonistas. Porto Alegre: Artmed, 2004. 